University of Nebraska - Lincoln

DigitalCommons@University of Nebraska - Lincoln

\title{
Digging Behaviors Of Radio-Tagged Black-Footed Ferrets Near Meeteetse, Wyoming, 1981-1984
}

Dean E. Biggins

U.S. Geological Survey, dean_biggins@usgs.gov

Louis R. Hanebury

Western Area Power Administration

Kathleen A. Fagerstone

National Wildlife Research Center, kathleen.a.fagerstone@aphis.usda.gov

Follow this and additional works at: https://digitalcommons.unl.edu/icwdm_usdanwrc

Biggins, Dean E.; Hanebury, Louis R.; and Fagerstone, Kathleen A., "Digging Behaviors Of Radio-Tagged Black-Footed Ferrets Near Meeteetse, Wyoming, 1981-1984" (2012). USDA National Wildlife Research Center - Staff Publications. 1104.

https://digitalcommons.unl.edu/icwdm_usdanwrc/1104

This Article is brought to you for free and open access by the U.S. Department of Agriculture: Animal and Plant Health Inspection Service at DigitalCommons@University of Nebraska - Lincoln. It has been accepted for inclusion in USDA National Wildlife Research Center - Staff Publications by an authorized administrator of DigitalCommons@University of Nebraska - Lincoln. 


\title{
DIGGING BEHAVIORS OF RADIO-TAGGED BLACK-FOOTED FERRETS NEAR MEETEETSE, WYOMING, 1981-1984
}

\author{
Dean E. Biggins ${ }^{1}$, Louis R. Hanebury ${ }^{2}$, and Kathleen A. Fagerstone ${ }^{3}$
}

\begin{abstract}
Intensive radio-tracking during August-December enabled us to collect detailed information on digging behaviors of a small sample of black-footed ferrets (Mustela nigripes) occupying colonies of white-tailed prairie dogs (Cynomys leucurus). A sample of 33 prairie dogs, also radio-tagged, progressively ceased aboveground activity during late summer and fall, presumably as they descended into burrows to hibernate. Most of the time ferrets spent digging was in November-December when $>95 \%$ of the radio-tagged prairie dogs were inactive, suggesting that digging was primarily to excavate hibernating prey. Although $43.9 \%$ of the burrow openings were estimated to be in large mounds, which are common on colonies of white-tailed prairie dogs, all of a sample of 17 deposits of soil (diggings) made by ferrets were excavated at small mounds or nonmounded openings. The average duration of 23 nocturnal sessions of digging by ferrets was 112.2 minutes. A digging session consisted of multiple bouts of soil movement typically lasting about 5 min, and sessions were separated by pauses above- or belowground lasting several minutes. Bouts of moving soil from a burrow involved round-trips of $12.5-30.3 \mathrm{~s}$ to remove an average of $35 \mathrm{~cm}^{3}$ of soil per trip. These digging bouts are energetically costly for ferrets. One female moved $16.8 \mathrm{~kg}$ of soil an estimated $3.3 \mathrm{~m}$ during bouts having a cumulative duration of 178 minutes, removing a soil plug estimated to be $178 \mathrm{~cm}$ long. Increasing evidence suggests that some behaviors of ferrets and prairie dogs are coevolutionary responses between this highly specialized predator and its prairie dog prey.
\end{abstract}

Resumen.-Mediante el uso intensivo del monitoreo por radio desde agosto hasta diciembre, logramos colectar información detallada sobre la conducta de excavación de una pequeña muestra de hurones de patas negras (Mustela nigripes) que habitan colonias de perros llaneros de cola blanca (Cynomys leucurus). Una muestra de 33 perros llaneros, también monitoreados por radio, cesaron gradualmente su actividad sobre el suelo durante finales del verano y el otoño, probablemente debido a que descendieron a sus madrigueras para hibernar. De noviembre a diciembre fue cuando los hurones pasaron la mayor parte de su tiempo cavando y cuando más del $95 \%$ de los perros llaneros monitoreados por radio no se encontraban activos, lo cual indica que las excavaciones se hacían primordialmente para extraer presas que estaban hibernando. A pesar de que se estima que el $43.9 \%$ de las madrigueras se encuentra en los montículos grandes que son comunes en las colonias de perros llaneros de cola blanca, de una muestra de 17 depósitos de tierra (excavaciones) realizados por hurones, todos se habían excavado en montículos pequeños o en madrigueras sin montículos. La duración promedio de 23 sesiones nocturnas de excavación realizadas por hurones fue de 112.2 minutos. Una sesión de excavación consistió de varios ratos de movimiento de tierra que típicamente duraban alrededor de 5 minutos, separados por pausas tanto sobre el suelo como en el subsuelo que duraban varios minutos. En estos ratos, se realizaban viajes de 12.5-30.3 segundos para remover $35 \mathrm{~cm}^{3}$ de tierra por viaje. Estas excavaciones de tierra consumen mucha energía de los hurones. Una hembra removió $16.8 \mathrm{Kg}$ de tierra a lo largo de una distancia de aproximadamente $3.3 \mathrm{~m}$ durante sus ratos de excavación, los cuales duraron 178 minutos en total y en los que logró remover un taponamiento de 178 cm de largo. Existen cada vez más evidencias que indican que algunos comportamientos de los hurones y los perros llaneros son respuestas coevolutivas entre este depredador altamente especializado y su presa, el perro llanero.

For most mammals that live in burrows, excavation and movement of soil is a fundamentally important behavior. Measurement of movement of substrate in various forms has become a common psychometric evaluation for psychologists who use rodents as models to study basic elements of behavior (DeBoer and Koolhaas 2003). Although black-footed ferrets (Mustela nigripes) are carnivores that spend much of their lives underground, they are not known to construct their own burrows and they commonly expropriate the burrows of their prairie dog (Cynomys spp.) prey. Ferrets do, however, actively move substrate and leave characteristic deposits of soil (diggings) on the surface of the ground as they modify burrow systems or remove soil plugs left by prairie dogs. These diggings have attracted much attention historically as indices to the presence of the highly endangered ferrets, and the identification of diggings has been discussed in detail. Descriptions have been provided for diggings

${ }^{1}$ U.S. Geological Survey, Fort Collins Science Center, Fort Collins, CO 80526. E-mail: dean_biggins@usgs.gov

${ }^{2}$ Western Area Power Administration, Billings, MT 59101.

${ }^{3}$ USDA/APHIS/Wildlife Services, National Wildlife Research Center, Fort Collins, CO 80525. 


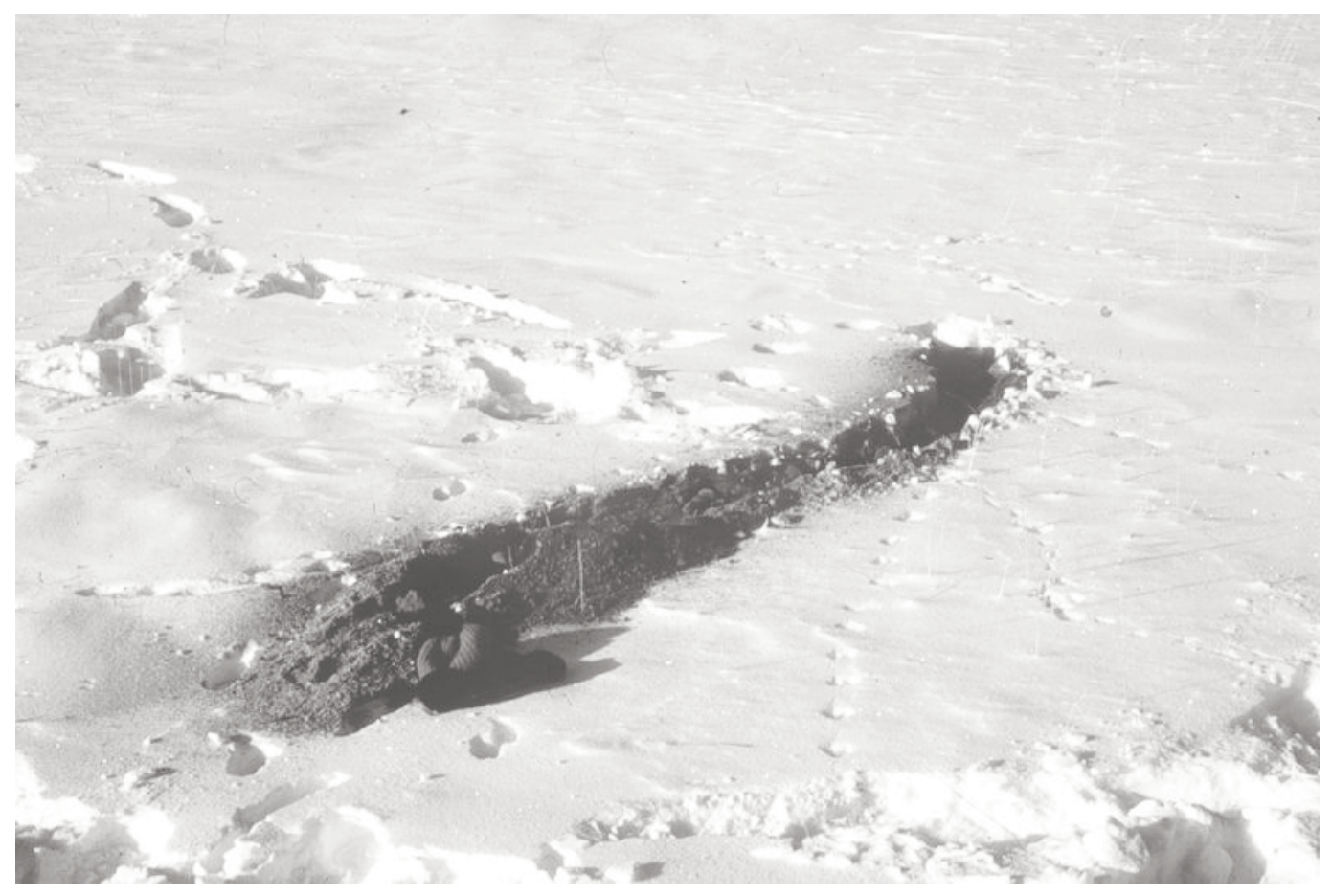

Fig. 1. A 1.8-m-long deposit of soil (digging) left by a black-footed ferret (Mustela nigripes) on white-tailed prairie dog (Cynomys leucurus) habitat near Meeteetse, Wyomimg. The larger twin prints are tracks of the ferret.

left by ferrets (Fig. 1) occupying colonies of black-tailed prairie dogs (Cynomys ludovicianus; Hillman 1968, Henderson et al. 1969, Fortenbery 1972) and habitat of white-tailed prairie dogs (Cynomys leucurus; Clark et al. 1984, 1986, Richardson et al. 1987, Clark 1989). The latter authors have implied, from circumstantial evidence on seasonal disappearance and reappearance of white-tailed prairie dogs, that black-footed ferrets (ferrets henceforth) dig at prairie dog burrows in winter to excavate hibernating prairie dogs that have plugged portions of tunnels. Others (Eads et al. 2012) have noted that digging by ferrets is common in summer, although abundant prairie dog activity can quickly render the soil deposits unrecognizable.

Radio-tracking of ferrets on white-tailed prairie dog colonies near Meeteetse, Wyoming, during 1981-1984 allowed us to collect data on diggings and digging behaviors as we worked on other studies (Fagerstone and Biggins 2011). The intensity of our radio-tracking procedures allowed us to accumulate detailed information on digging behaviors for a small sample of ferrets. These indirect methods allowed us to remotely sense relatively uninhibited behaviors, avoiding the disturbance to subjects caused by the immediate presence of human observers. In this paper, we examine durations of ferret digging sessions, apparent pauses during digging sessions, elapsed times for round-trips to remove soil from burrows, volume and mass of soil removed, distances soil was moved, and amounts of soil moved per trip. Because our study included data collected on radio-tagged prairie dogs, we were able to examine their disappearance in late summer through fall, presumably due to entry into hibernation. Based on these concurrently collected telemetric data on ferrets and prairie dogs, we reexamine the potential relationship between timing of ferret digging and prairie dog hibernation.

\section{Methods}

The study area was a complex of 33 whitetailed prairie dog colonies (approximate center of complex at $44^{\circ} 09^{\prime} \mathrm{N}, 109^{\circ} 08^{\prime} \mathrm{W}$ ) at elevations of 1980-2290 m near Meeteetse, Wyoming (Forrest et al. 1985). Although we collected data 
on various prairie dog colonies by using handling, radio-tracking, and other techniques, only portions of our 1981-1984 data sets were suitable for the analyses of this study. Observations on digging by radio-tagged ferrets came from the East Core Colony (738.5 ha), the West Core Colony (568.5 ha), and the Pump Station Colony (230.0 ha) during 1983-1984.

Capture, radio-tagging, and tracking procedures have been detailed elsewhere (Biggins et al. 2006, Fagerstone and Biggins 2011). We located ferrets with spotlights, captured them with tubular wire-mesh traps, handled them under anesthesia, and fitted them with radio-collars (Biggins et al. 1985). During 1983, we weighed ferrets when they were recaptured for replacement of radio-collars. During 1984, we radio-tracked both prairie dogs and ferrets from fixed stations and a few mobile stations. We captured prairie dogs on the Pump Station Colony in August with Tomahawk traps (Tomahawk Live Traps, Tomahawk, WI 54487) using grain baits and radio-collared them with $20-\mathrm{g}$ collars while they were under anesthesia. We radio-tracked the prairie dogs from fixed stations using procedures identical to those described for ferrets.

Detailed telemetric data (interfix intervals 3-8 min) on digging behaviors of ferrets were collected in 1983 on 5 individual ferrets (Fagerstone and Biggins 2011). Telemetric monitoring was continuous when only a single ferret was being radio-tracked, enabling the most detailed collection of data on digging behavior. We identified digging as the rhythmic appearance and disappearance of the radio signal when the ferret repeatedly dragged soil from a burrow and reentered the burrow. When interpreting these activities using radiotelemetry, we assumed that presence of a telemetric signal indicated the ferret was aboveground and that lack of a telemetric signal was due to attenuation from soil when the ferret was belowground. We received signals from transmitters that were at shallow depths belowground when conditions were optimal (e.g., short range, topographic line of sight, matched polarities of receiving and transmitting antennas). There was a potential for underestimating the frequency of digging because (1) powerful radio signals were necessary to discern the necessary details of signal amplitude, (2) tracking of multiple ferrets sometimes compromised detailed information for a single ferret, and
(3) some radio-trackers were less skilled than others at detection of the signal signatures characteristic of digging.

We also observed digging behavior of ferrets directly, using spotlights for illumination. Although red lights were thought to reduce the impact on ferret behavior, the potential impact of observer presence remained. We thus believe the remotely sensed telemetric data were more reliable than direct observation of ferrets for characterizing the attributes of their digging behavior, and we used the telemetric data for analyses herein. Nevertheless, several direct observations coupled with simultaneous radio-tracking from fixed stations enabled calibration and interpretation of signal patterns that defined digging behaviors. These comparisons were facilitated by 2 -way radio communication between observer and radio-tracker.

We defined a session of digging as the interval of time beginning with first detection of digging behavior and ending at the last such detection during that night of radio-tracking. We defined a bout of soil movement as a series of uninterrupted alternations of signal presence and absence with durations of 2-25 s each. A session had one or more bouts of digging that were often interrupted by pauses of $>25 \mathrm{~s}$ above- or belowground. We telemetrically monitored portions of bouts during which ferrets were moving soil from within the burrow to deposit sites outside the burrow. When telemetric signals were strong, rhythmic disappearance and reappearance of the signal was associated with submergence of the ferret belowground followed by returns to the surface. We confirmed the association between these signal patterns and digging behavior through direct observation on several occasions (i.e., watching the ferret bring soil from the burrow entrance and finding deposits of soil at the location determined for the ferret via triangulation). We estimated elapsed times of round-trips to transport soil by using a sample of 212 timed intervals of telemetric signal loss and recurrence taken from 16 bouts of digging for 3 ferrets.

Because most winter plugs in white-tailed prairie dog burrows do not seem observable from the surface and because the soils of the mounds surrounding some burrows remain relatively undisturbed in winter, we assume that these subsurface plugs are constructed by white-tailed prairie dogs using soil excavated 
belowground. The total distance travelled by the ferret to excavate an underground plug includes the distance it must move within the burrow to reach the plug plus the distance it must move across the soil deposit it leaves aboveground. Deposits can be $>3 \mathrm{~m}$ long, but single-lobed deposits average $1.4 \mathrm{~m}$ (Clark 1989:84). Calculation of the total distance traveled during a trip to remove soil relied on estimates of ferret speeds using their normal bounding pace, their speeds when pulling soil from the burrow (backwards), and the elapsed time for a round-trip. We used a normal rate of movement for ferrets engaged in a leisurely bounding gait. The rate was derived from timed movements over short distances during observations of captive ferrets in outdoor pens $\left(0.446 \mathrm{~m}^{\cdot} \mathrm{s}^{-1} ; \mathrm{CI}_{0.05}\right.$ 0.363-0.577; DEB personal observation). Ferrets move soil by dragging it backward with their front feet, a phenomenon we have observed repeatedly. Because most of this activity occurs belowground, timing of the speed is difficult. We approximated the speed by timing a ferret envisioned to be moving soil backward over a 2.5-m distance and assuming that belowground speeds are the same as those aboveground speeds. The mean of 6 such simulations (by DEB) produced an estimated rate of $0.159 \mathrm{~m} \cdot \mathrm{s}^{-1}\left(\mathrm{CI}_{0.05}\right.$ 0.145-0.179). The formula we used to calculate distance was

$$
d=T \cdot \frac{\left(r_{n} \cdot r_{d}\right)}{\left(r_{n}+r_{d}\right)},
$$

where $d=$ distance, $T=$ total time for a round trip (s), $r_{n}=$ normal rate of ferret movement $\left(\mathrm{m} \cdot \mathrm{s}^{-1}\right)$, and $r_{d}=$ rate of ferret movement $(\mathrm{m} \cdot$ $\left.\mathrm{s}^{-1}\right)$ when transporting soil.

White-tailed prairie dog burrow openings can have diameters as small as $7 \mathrm{~cm}$ (Biggins et al. 1993), and openings $>18 \mathrm{~cm}$ were considered to be reamed by badgers (Richardson et al. 1987). We calculated lengths of soil plugs within burrows assuming that the burrows had an average diameter of $10 \mathrm{~cm}$ and that the ferret excavated the plug to the full diameter of the burrow, using the formula

$$
L=\frac{V}{(d / 2)^{2} \cdot \pi}
$$

where $L=$ length of plug $(\mathrm{cm}), V=$ volume of excavated soil $\left(\mathrm{cm}^{3}\right), d=$ diameter of burrow opening $(\mathrm{cm})$, and $\pi=3.14159$.
We examined 17 photos of ferret diggings taken at the Meeteetse habitat during 19811984 to determine the types of burrow openings at which digging occurred. The photos, taken opportunistically during October-March, show a wide variety of digging types and sizes (Clark et al. 1984). Although we did not attempt to accumulate a random sample, we believe they are representative of diggings at the Meeteetse habitat, based on our observations of many such soil deposits in the Meeteetse area and on our belief that photos were taken when cameras were available rather than when unusual types of deposits were found. We are convinced that we paid no attention to type of mound (the primary attribute analyzed here) when we photographed diggings. We classified burrow openings as associated with a large mound, a small mound (a mound that surrounded at least $2 / 3$ of the burrow opening), or no mound (Richardson et al. 1987). In 1982, we mapped all burrow openings on a portion of the West Core Colony (Biggins et al. 1985), classifying the openings similarly. Using chisquare tests of independence, we compared openings at which diggings were found and photographed with proportions of openings of each type present based on the West Core map. We evaluated chi-square values with the exact chi-square procedure (Berry and Mielke 1985).

\section{RESUlTS}

We monitored 23 sessions of digging by 5 individual ferrets during August-December. Of these sessions, $78 \%$ were detected in NovemberDecember, and $86 \%$ of the total time spent digging was in November-December. About $50 \%$ of the radio-tagged prairie dogs had disappeared belowground by 1 October (excluding those that had been killed by predators or whose radio-collars were removed), and only about $4 \%$ remained active by 3 November (Fig. 2). Thus, most ferret digging was detected when most prairie dogs had ceased their aboveground activity.

The average digging session for ferrets occupied $112.2 \mathrm{~min}(\mathrm{SD}=77.1 \mathrm{~min})$ overall. On nights when ferrets engaged in digging, their digging sessions occupied $25.5 \%$ of the time they were monitored telemetrically. The average duration of 106 round-trips to move soil within 16 partial bouts was $19.61 \mathrm{~s}(\mathrm{SD}=6.92$, range $12.50-30.29 \mathrm{~s})$. This average round-trip 


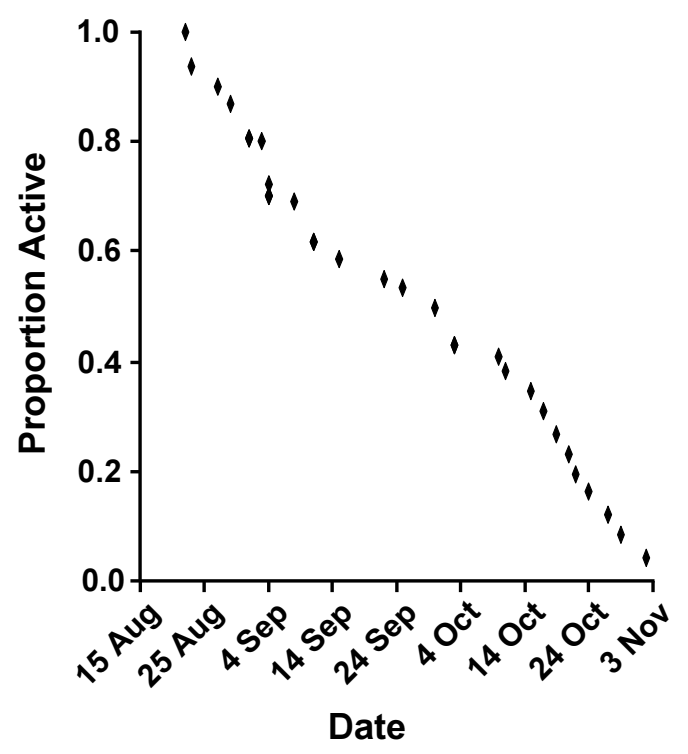

Fig. 2. Proportion of 31 radio-tagged white-tailed prairie dogs (Cynomys leucurus) remaining active through late summer and fall of 1983 at the Pump Station Colony near Meeteetse, Wyoming. Denominator was reduced as prairie dogs were killed by predators $(n=3)$ or their radio-collars were removed $(n=4)$.

results in an estimated total distance traveled of $2.31 \mathrm{~m}$. Assuming that the soil deposits associated with the 106 round-trips were half completed on average, the distance traveled by a ferret across the deposit would have been about $0.7 \mathrm{~m}(1.4 \mathrm{~m} \cdot 0.5$; Clark 1989), making the distance traveled within the burrow about $1.61 \mathrm{~m}$.

The session of digging for ferret 10-83 on 3 November 1983, beginning at 01:10 when she first appeared aboveground and lasting $165 \mathrm{~min}$, was a particularly well-documented example of this behavior. Timing of various elements in the session began at 01:28 (Fig. 3). There were $85 \mathrm{~min}$ (16 bouts, $\bar{x}=5.31 \mathrm{~min}$, $\mathrm{SD}=3.65)$ involving numerous round-trips to move soil to the surface, with rhythmic disappearances of the telemetric signal for about $8 \mathrm{~s}$ and reappearances of the signal for about $8 \mathrm{~s}$ (16-s round-trips). Interspersed among these bouts to move soil were 11 periods when the ferret lingered aboveground $(\bar{x}=2.00 \mathrm{~min}$, $\mathrm{SD}=0.89$ ) and 11 additional periods when the ferret lingered belowground $(\bar{x}=4.27 \mathrm{~min}$, $\mathrm{SD}=2.20)$.

We collected the soil deposits made by radio-tagged ferrets on 4 occasions ( 3 occasions for female ferret $10-83$ and 1 for male ferret
02-83) and related measurements of excavated soil to data from intensive radio-tracking of the ferrets while they were digging (Table 1). Estimated lengths of soil plugs removed were 68-190 cm (Table 1). We believe the soil deposit collected after the 14 November digging session by ferret 10-83 was made entirely during her digging sequence on that day, as we were able to track ferret $10-83$ continuously at night from 9 November through 17 November. For other occasions, we cannot be certain that soil deposits were made entirely during the period of radio-monitoring. However, on 17 November radio-tracking of 10-83 did not begin until 73 min after sunset, and she was digging when tracking began. Thus the time spent digging might be underestimated, but the entire soil deposit (located about $60 \mathrm{~m}$ from the digging discussed above) probably was created during that evening. For ferret 10-83 on 1 December and ferret $02-83$ on 24 November, we do not have complete radio-tracking records before the night their digging was monitored, so some of the soil in the deposits collected could have been excavated on other nights. The rate of soil movement for male ferret 02-83 on 24 November was about double that of the most reliable estimate for female ferret 10-83. Although ferret 02-83 was much larger (1035 g on 16 November) than ferret 10-83 (730 g on 10 November), much of the disparity in digging rates could have been due to previous accumulation of excavated soil in the deposit made by the male rather than the differences in ferret sizes.

Although $43.9 \%$ of 2641 burrow openings were estimated to be in the large mounds common on the West Core white-tailed prairie dog colony, all of the 17 photographed diggings made by ferrets were excavated at small mounds or nonmounded openings $\left(\chi^{2}{ }_{1}=13.269, P<\right.$ $0.001)$. Examined in another way, a large mound $(n=575)$ was considered as an individual site having one or more burrows, and each singleopening (whether in a small mound or nonmounded) also was considered as an individual site. Using this approach, none of the diggings were at large mound sites, which comprised $28.0 \%$ of the 2055 sites with burrow openings; these are still substantially different proportions than expected by random chance $\left(\chi^{2}{ }_{1}=6.584\right.$, $P=0.010)$. Thus, ferret avoidance of large white-tailed prairie dog mounds for excavation occurred at the scales both of individual burrows and sites. 


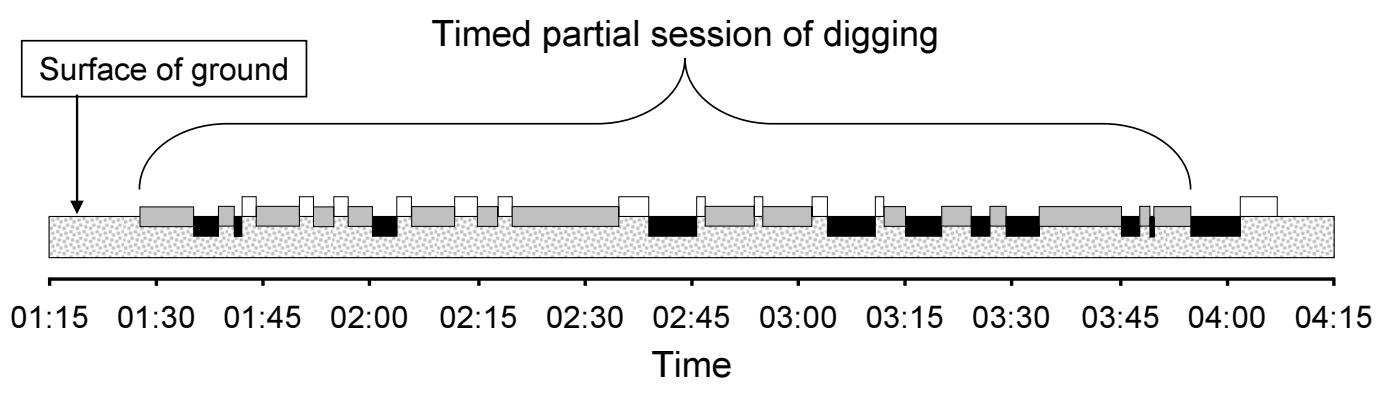

\section{Pauses above ground $\square$ Pauses below ground $\square$ Moving soil from burrow}

Fig. 3. Schematic time line showing a portion of a digging session for ferret 10-83 on 3 November 1983. Bouts of moving soil from burrows had an average duration of $5.31 \mathrm{~min}(\mathrm{SD}=3.65)$, involving 20 round trips of about $16 \mathrm{~s}$ each.

TABLE 1. Attributes of 4 sessions of digging and associated soil deposits for 2 radio-tagged black-footed ferrets.

\begin{tabular}{lcccc}
\hline & \multicolumn{3}{c}{ Ferret individuals } \\
\cline { 2 - 4 } & $10-83(q)$ & $10-83(q)$ & $10-83(q)$ & $02-83(\hat{\jmath})$ \\
\hline Start digging-month/day (hour:min) & $11 / 14(01: 45)$ & $11 / 17(18: 42)$ & $12 / 01(00: 15)$ & $11 / 24(22: 45)$ \\
End digging-month/day (hour:min) & $11 / 14(07: 01)$ & $11 / 17(19: 39)$ & $12 / 01(02: 04)$ & $11 / 25(01: 52)$ \\
Bouts of digging & 3 & 1 & 1 & 3 \\
Cumulative minutes of moving soil & 178 & 57 & 109 & 74 \\
$\quad$ within sessions & 16.8 & 6.5 & 20.3 & 15.9 \\
Soil mass $(\mathrm{kg})$ & 13,955 ) & 5322 & 13,263 & 201.4 \\
Soil volume $\left(\mathrm{cm}^{3}\right)$ & 78.4 & 93.4 & 122.6 & 22.4 \\
Soil moved per minute & & & 13.3 \\
$\quad\left(\mathrm{~cm}^{3}\right.$ within sessions) & 28.1 & 29.4 & 1.56 & 2.63 \\
Average round trip time $(\mathrm{s})$ & 3.30 & 3.46 & 24.90 & 75.00 \\
One-way distance $(\mathrm{m})$ & 36.50 & 45.80 & 170 & 190 \\
Soil moved per trip $\left(\mathrm{cm}^{3}\right)$ & 178 & 68 & & \\
Length of burrow plug $(\mathrm{cm})$ & & & \\
\hline
\end{tabular}

\section{Discussion}

Richardson et al. (1987) observed digging activity nearly every night for Meeteetse ferrets that were snow-tracked during DecemberMarch 1981-1984. Considering (1) our averages for time spent digging per session in NovemberDecember (1.87 h), (2) an estimated nightly activity of 2.10-2.95 h (Biggins et al. 1986), and (3) the Richardson et al. (1987) data, it seems that digging activity might dominate the ferrets' activity budget during winter. Our data support the hypothesis that an increase in digging activity by ferrets in late summer through fall is due to an increase in proportion of hibernating white-tailed prairie dogs. Although our data on rates of digging are sparse, digging by ferrets did not seem to increase proportionately with the gradual disappearance of prairie dogs aboveground (Fig. 2), but it did increase abruptly in November. Ferrets apparently continued to hunt the declining number of active prairie dogs as long as they could do so. This suggests that excavation of hibernating white-tailed prairie dogs by ferrets has an energetic cost that exceeds the costs of hunting active prairie dogs. There is an additional implication that the ability to kill the presumably unresponsive hibernating prey does not add sufficient benefit to make hunting via excavation preferable to hunting active prairie dogs.

The details of digging by ferret 10-83 on 3 November 1983 revealed pauses aboveground and belowground between bouts when this ferret was actively moving soil (Fig. 3). Perhaps the underground interludes (when no radio signals were detected) were to rest and to loosen soil for later removal. The aboveground pauses were likely periods of rest and perhaps reconnaissance for badgers (Taxidea taxus) that might attempt to corner ferrets in the presumably plugged tunnel that they are excavating 
(Biggins 2012). The estimated 319 round-trips $(\bar{x}=[85 \mathrm{~min} \cdot 60 \mathrm{~s}] / 16 \mathrm{~s}$ per trip) suggest a large expenditure of energy. An additional perspective on energetic costs of digging comes from the realization that ferrets moved up to 28 times their body weight (Table 1) uphill and backward over a distance of about 6 times their body length during a digging session.

Clark (1989) suggested that digging continues at a site for extended discontinuous periods; 15 diggings measured repeatedly increased an average of $20.3 \mathrm{~cm}$ in length over a 21-64 d period. The average volume of 4 diggings we measured $\left(11,885 \mathrm{~cm}^{3}\right)$ was similar to the average volume $\left(10,400 \mathrm{~cm}^{3}\right)$ reported by Clark (1989), notwithstanding a potential increase in size of diggings over time and a corresponding underestimate of plug length due to our use of average sizes of diggings (because some measurements might be for diggings in progress). These volumes translate into estimated average lengths of plugs (using our formula) of $151 \mathrm{~cm}$ and $132 \mathrm{~cm}$, respectively. Because these plugs seem to be longer than necessary to moderate the climate of the burrow (to facilitate hibernation), the extensive plugging might be an evolutionary response to predation by ferrets.

Ferrets visit many burrow systems during their winter travels on white-tailed prairie dog habitat (Richardson et al. 1987), so it seems reasonable that one of the purposes of those visits might be to assess prey availability. If white-tailed prairie dogs hibernate alone and ferrets can sense (perhaps via olfaction; Biggins et. al 2012) the length of a plug to estimate energetic costs of excavation, intraspecific competition among prairie dogs for protection from winter raids by ferrets might have provided the selective pressure for prairie dogs to evolve a propensity to construct long plugs. The potential presence of multiple prairie dogs in a single hibernaculum might change the cost-benefit ratio of plugging by the prairie dogs (and creation of long plugs) and excavation by the ferrets. In addition to an ability to sense length of plugs, it would seem advantageous for ferrets to be able to sense the number of prairie dogs present if white-tailed prairie dogs hibernate communally (which is unknown). Radio-tagged prairie dogs are difficult to locate underground because of signal attenuation by the soil, but the few that have been located in this and other studies after commencement of hibernation were not located together (DEB unpublished data).

We speculate that winter predation on hibernating prairie dogs by ferrets has led prairie dogs to create plugs below the surface. We estimated that the typical midpoint of a whitetailed prairie dog burrow plug was about $1.6 \mathrm{~m}$ from an opening, but the vertical distance remained unknown. It seems to be energetically costly to remove this soil from the depths where plugging presumably occurs (Biggins et al. 2012). Plugging at depth instead of near the surface supports the explanation of predator avoidance because costs of soil removal by ferrets would increase according to length, depth, and incline of the tunnel (Luna and Antinuchi 2007). In theory, all but one of the multiple openings of burrow systems commonly used by prairie dogs could be plugged from the surface for climate modification. The lesscompacted soil at the surface (including soil on mounds) should be easier and less costly to manipulate than undisturbed subsurface soils. Despite these presumed advantages of plugging from the surface, white-tailed prairie dog burrows show little evidence of surface plugging during winter.

The ferret diggings we measured in the field were similar to those measured by others on white-tailed prairie dog habitat. Our small sample was $80 \%$ single-lobed in structure with an average length of $122 \mathrm{~cm}$. In comparison, the sample of Clark et al. (1984) was $89 \%$ singlelobed with an average length of $140 \mathrm{~cm}$. None of the diggings we photographed were at mounds, in stark contrast to the situation on black-tailed prairie dog colonies, where most ferret digging occurred at mounded burrow openings (Eads and Biggins unpublished data). We assume that mounded openings must be linked by tunnels to nonmounded openings, as on colonies of black-tailed prairie dogs, to create multi-opening systems (for reasons relating to sequence of construction-Biggins et al. 2012). We speculate that the difference between burrow systems of black-tailed prairie dogs and whitetailed prairie dogs might relate to the obligatory hibernation of white-tailed prairie dogs and the attendant subsurface plugging of tunnels leading from the hibernaculum to the surface. Prairie dogs would presumably avoid tunnels with steep angles of ascent when plugging them from underground because soil would be difficult to move up steep inclines 
and would not tend to remain in place when left unattended. These nearly vertical tunnels are described for black-tailed prairie dogs by Sheets (1970), who presumed that burrow construction left a mound at the origin of the system (given this is where digging starts) and that the passage constructed leads underground to a vertical tunnel where the prairie dog ascends to the surface to create an additional opening. White-tailed prairie dogs likely use the same burrow-building sequence because it remains illogical that openings to extensive tunnel systems could be created by excavation from the surface without leaving considerable residual soil near the initial opening. However, if burrow systems of white-tailed prairie dogs had similar vertical tunnels leading to nonmounded openings, ferrets would not be expected to excavate soil from them due to the difficulty of moving soil vertically to the surface. Thus, it seems that white-tailed prairie dogs dig their way back to the surface gradually, creating at least some of the additional openings (Biggins 2012) to their systems with tunnels of moderate incline, which allows excavation by ferrets.

Theoretically, white-tailed prairie dogs could close vertical tunnels before hibernation by plugging them with surface soil and then make their final descent into the tunnel of the mounded opening, which they would plug from below. Under this scenario, however, returning the burrow system to its original condition would involve an energetically expensive longdistance movement of the soil from the vertical tunnels past the hibernaculum chamber and out through the mounded opening with the gradual slope (given that prairie dogs, like ferrets, could not move soil upward through a vertical tunnel). Also, plugging from the surface presumably would be more energetically costly in vertical than in sloping tunnels because vertical tunnels might be nonmounded (Biggins et al. 2012) and less-compacted soil would be available only at the mounded openings with sloping tunnels.

It remains puzzling that we did not find ferret diggings on openings within the large mounds of white-tailed prairie dogs. Indeed, openings at these large mounds appear to be visited by ferrets at a higher-than-expected frequency in winter (Richardson et al. 1987). If tunnels have at least 2 openings with a hibernaculum between them, perhaps the hibernacula of white-tailed prairie dogs tend to be farther from burrow openings in large mounds than they are from nonmounded openings. Thus, soil from plugs would need to be moved over correspondingly greater distances by ferrets. Furthermore, plugs might be longer in sections of burrows between hibernacula and openings in mounds than between hibernacula and openings without mounds. Finally, openings in mounds would tend to be slightly higher than openings level with the surface of the ground. Movement of soil to this higher elevation would require slightly higher energetic costs for ferrets.

If white-tailed prairie dogs obtain soil for plugging by digging new tunnels, what is the ultimate destination of this soil? Upon reemergence in spring, the prairie dogs presumably reopen plugged tunnels. Do they move the soil back into the tunnels from which it came, or do they move it to the surface? Excavated soil is presumably less dense than soil that likely has not been disturbed for millennia, so merely moving the soil back into the tunnel of origin would leave a surplus. Perhaps the entire amount of soil, or just the surplus, is moved to a surface mound that continues to grow over time, creating the large, multi-entrance structures common for white-tailed prairie dogs. The excavation of new tunnels to obtain soil for plugging could serve a dual purpose: creating new tunnels that are ultimately opened to the surface and thereby forming new potential escape routes that can be used to evade subterranean predators (e.g., snakes, ferrets, badgers) in summer.

The logic above leads to speculation that winter predation on hibernating prairie dogs by ferrets has led those prairie dogs to create long plugs, the management of which may lead to larger mounds. Utah prairie dogs (Cynomys parvidens), an obligate hibernator in the whitetail subgenus, have not historically served as prey for ferrets. Perhaps Utah prairie dogs have lacked predation by a ferret-like carnivore for a sufficiently long period to evolve a different strategy for protection against predators and winter climates. It would be useful to compare mound and burrow morphology on Utah prairie dog colonies with that of whitetailed prairie dogs and Gunnison's prairie dogs (Cynomys gunnisoni). This comparison would test the prediction that the latter will make longer winter plugs, which will lead to larger mounds with more connected openings. We 
suspect, however, that the introduction of plague to North America has resulted in shorter mean life spans for colonies of all 3 species. This could affect the balance between burrow construction and attrition rates, ultimately resulting in less burrow complexity than in historic times. If the burrow attributes discussed above are long-term developments, it may be more difficult now to detect these kinds of effects of ferret presence.

The several lines of speculation above could lead to additional avenues of investigation into the interactions of prey with a highly specialized predator. As a highly social group of species using group tactics to detect and communicate danger, prairie dogs might have increased their defenses against surface and aerial predators at the expense of defenses against subterranean predators (Hamilton 1971, Hoogland 1981), but prairie dogs do not lack defenses against the latter (including ferrets; Biggins et al. 2012). Sparse historic information on distributions of ferrets seemed to have misled Powell (1981) regarding the nature of differences in the evolution of defenses of black-tailed and white-tailed prairie dogs in response to ferrets. However, his expectation that the specialist ferret would cause intense selective pressure on prairie dog behavior is supported by data reported here and elsewhere. Our discussion lengthens the growing list of potential adaptations that might be attributed to coevolution of these animals, including some adaptations that ultimately manifest themselves as attributes of the burrow systems constructed and modified by prairie dogs and the behaviors of the ferrets hunting their occupants.

\section{ACKNOWLEDGMENTS}

We thank the ranchers of the Meeteetse area for access to their lands and many entertaining discussions. Our sincere appreciation goes to the many radio-trackers who spent long nights watching their coffee freeze on the table of the tracking station while listening to telemetric radio signals from ferrets (occasionally) and static (usually). We received helpful comments on this manuscript from D. Eads and S. Breck. This research was completed while the authors were with the Department of the Interior, United States Fish and Wildlife Service, Denver Wildlife Research Center (DWRC). Any use of trade, product, or firm names is for descriptive purposes only and does not imply endorsement by the United States Government.

\section{Literature Cited}

Berry, K.J., AND P.W. Mielke JR. 1985. Subroutines for computing exact chi-square and Fisher's exact probability tests. Education and Psychological Measurement 45:153-159.

BigGins, D.E. 2012. Use of multi-opening burrow systems by black-footed ferrets. Western North American Naturalist 72:134-139.

Biggins, D.E., J.L. Godbey, B.J. Miller, and L.R. Hanebury. 2006. Radio-telemetry for black-footed ferret research and monitoring. Page 175-189 in J.E. Roelle, B.J. Miller, J.L. Godbey, and D.E. Biggins, editors, Recovery of the black-footed ferret-progress and continuing challenges. U.S. Geological Survey Scientific Investigations Report 2005-5293.

Biggins, D., B. Miller, L. Hanebury, R. Oakleaf, A. Farmer, R. Crete, AND A. Dood. 1993. A technique for evaluating black-footed ferret habitat. Pages 73-88 in J. Oldemeyer, D. Biggins, B. Miller, and R. Crete, editors, Management of prarie dog complexes for reintroduction of the black-footed ferret. U.S. Fish and Wildlife Service, Biological Report, 1993-13.

Biggins, D.E., S. Ramakrishnan, A.R. Goldberg, and D.A. EADs. 2012. Black-footed ferrets and recreational shooting influence the attributes of blacktailed prairie dog burrows. Western North American Naturalist 72:158-171.

Biggins, D.E., M.H. Schroeder, S.C. Forrest, and L. Richardson. 1985. Movements and habitat relationships of radio-tagged black-footed ferrets. Pages 11.1-11.17 in S. Anderson and D. Inkley, editors, Proceedings of the Black-footed Ferret Workshop. Wyoming Game and Fish Department, Cheyenne, WY.

1986. Activity of radio-tagged black-footed ferrets. Great Basin Naturalist Memoirs 8:135-140.

Clark, T.W. 1989. Conservation biology of the black-footed ferret Mustela nigripes. Wildlife Preservation Trust Special Scientific Report Number 3, EcoHealth Alliance, New York, NY.

Clark, T.W., L. Richardson, D. Casey, T.M. Campbell III, AND S.C. FORREST. 1984. Seasonality of blackfooted ferret diggings and prairie dog burrow plugging. Journal of Wildlife Management 48:1441-1444.

Clark, T.W., L. Richardson, S.C. Forrest, D.E. Casey, and T.M. Campbell III. 1986. Descriptive ethology and activity patterns of black-footed ferrets. Great Basin Naturalist Memoirs 8:115-134.

De Boer, S.F., and J.M. Koolhaas. 2003. Defensive burying in rodents: ethology, neurobiology and psychopharmacology. European Journal of Pharmacology 473:145-161.

Eads, D.A., D.E. Biggins, D. Marsh, J.J. Millspaugh, AND T.M. LIVIERI. 2012. Black-footed ferret digging activity in summer. Western North American Naturalist 72:140-147.

Fagerstone, K.A, AND D.E. Biggins. 2011. Black-footed ferret areas of activity during late summer and fall at Meeteetse, Wyoming. Journal of Mammalogy 92: 705-709. 
Forrest, S.C., T.W. Clark, L. Richardson, and T.M. CAMPBELL III. 1985. Black-footed ferret habitat: some management and reintroduction considerations. Wyoming Bureau of Land Management Wildlife Technical Bulletin No. 2.

FortenberY, D.K. 1972. Characteristics of black-footed ferrets. U.S. Fish Wildlife Service Resource Publication 109.

Hamilton, W.D. 1971. Geometry for the selfish herd. Journal of Theoretical Biology 31:295-311.

Henderson, F.R., P.F. SpRInger, AND R. AdRIAN. 1969. The black-footed ferret in South Dakota. South Dakota Department of Game, Fish and Parks, Technical Bulletin 4:1-37.

Hillman, C.N. 1968. Life history and ecology of the black-footed ferret in the wild. Master's thesis, South Dakota State University, Brookings, SD.

Hoogland, J.L. 1981. The evolution of coloniality in white-tailed and black-tailed prairie dogs (Sciuridae:
Cynomys leucurus and C. ludovicianus). Ecology 62:252-272.

LunA, F., AND C. ANTINUCHI. 2007. Effect of tunnel inclination on digging energetics in the tuco-tuco, Ctenomys talarum. Naturwissenschaften 94:100-106.

Powell, R.A. 1981. Prairie dog coloniality and blackfooted ferrets. Ecology 63:1967-1968.

Richardson, L., T.W. Clark, S.C. Forrest, and T.M. CAMPBELL. 1987. Winter ecology of the black-footed ferret at Meeteetse, Wyoming. American Midland Naturalist 117:225-239.

ShEETs, R.G. 1970. Ecology of the black-footed ferret and the black-tailed prairie dog. Master's thesis, South Dakota State University, Brookings, SD.

Received 22 July 2011 Accepted 8 May 2012 